\title{
1 \\ The first meeting: Brussels 1853
}

The genesis of international statistics was inspired by a desire for reform. At the Great Exhibition of 1851 Adolphe Quetelet, born in Ghent in 1796, recognised that Europe was on the cusp of great economic and scientific breakthroughs. Knowledge about the changes taking place was of primary importance if the pace of reform and balance in society were to be maintained. Statistics could provide the information required, but there was no shared body of knowledge about statistics. In Europe, statisticians did not know how others in their field defined statistics or how they were conducting statistical research. So Quetelet invited everyone who was occupied with the subject to Brussels to share their ideas. The scientific congress was a relatively new form of communication that was generating a lot of enthusiasm. It was not difficult to entice the crème de la crème of European statistical practice to the Belgian capital.

At midnight on Thursday 15 September 1853, Carl Friedrich Wilhelm Dieterici, director of the Prussian Statistical Office, boarded the night train in Berlin to travel to the congress that would officially begin on 19 September. Taking a train to an international congress on statistics would have been inconceivable just ten years earlier. All the signs indicated that a new Europe was in the making. Dieterici made appreciative use of the new connections and decided to stop in Dortmund, a city on the rise in the western provinces of the Kingdom of Prussia. He arrived at Dortmund station at half past five in the morning. Dieterici was impressed by the growth of the iron and coal industry, and collected material so that he could report on Dortmund to the interior minister when he returned to Berlin. The statistician was determined that the government should have up-to-date factual information in order to monitor the rapid industrialisation of the Ruhrgebiet. This was, after all, one of his office's tasks. After touring the Dortmund area all day, on Friday evening he travelled on to Aachen, where he spent the night before continuing his journey on 
Saturday. As he dutifully noted in his report, he arrived at the Prussian mission in the Belgian capital shortly after three oclock in the afternoon.

Dieterici's next destination was the home of Adolphe Quetelet, the architect and host of the congress. The two men had been corresponding professionally for years but had never met in person. Dieterici was immediately impressed. Quetelet was the consummate scientist, a man who was 'sustained and animated by scientific ideas and views.' The Belgian was also an extremely courteous man who felt at ease in the highest circles. Dieterici believed that Quetelet's excellent standing with the government was the reason statistics was thriving in Belgium. Quetelet told his German colleague Dieterici that it was Humboldt who had urged him to pursue a scientific career and that he had visited Johann Gottfried Hoffmann, Dieterici's predecessor, in Berlin back in the 1820s. Hoffmann gave him a tour of the Royal Statistical Office, which he had founded in 1805. That visit reinforced Quetelet's conviction that statistics was the science of the future, the science that could cultivate prosperity and progress. Though he had been educated as a mathematician and astronomer, he devoted himself to statistics with even greater zeal. Quetelet told Dieterici: 'In the same way that astronomy surveys the celestial bodies and meteorology studies the currents of air, wind and weather, statistics examines the risks that threaten society. ${ }^{2}$ Dieterici was completely won over by Quetelet, and he was not the only one.

That same week some 150 statisticians from every corner of Europe - official government representatives, academics and interested individuals - gathered in Brussels to attend the international statistical congress. They shared a passion for statistics (which was somewhat different from an obsession with numbers), but were it not for the gravitational force of Quetelet's personality, they probably never would have sought each other out. It helped that Quetelet was Belgian. Belgium was a guiding nation for progressive Europe. As a small, neutral, nonthreatening country, it could afford to assert a certain degree of independence from the great powers. The revolutions of 1848 did not leave Belgium wholly unscathed, but the political fallout was less dramatic than elsewhere. Radical democrats had had the wind taken out of their sails when the government of Charles Rogier introduced reforms, and a conservative reaction was unthinkable in the young, liberal, unitary state. Belgium had a constitution and a liberal representative system, and could boast of a reasonably stable parliamentary culture. The Belgian constitution of 1831 served as a model for the constitutional law code permitted by King Charles Albert of Sardinia of the House of Savoy in Piedmont in 1848. Belgium's municipal act of 1836 was studied carefully in Turin and The Hague, when the Piedmontese and Dutch governments were devising new local government laws in the late 1840s.

Dieterici, who had briefly been a member of the upper house of the Prussian parliament in 1848, would probably have felt comfortable in the liberal, academic atmosphere of the Belgian capital, though he could not have said so in his official report to the minister. In 1848 he had expressed a positive view of the liberal-nationalist Frankfurt Parliament, but at the same time condemned every radical tendency. Dieterici had classical liberal ideas, believed in the state 
and in effective legislation, but only if its object was to safeguard the freedom of capital and labour. With this essential restriction he distanced himself from every idea that tended towards socialism. In his view, statistics was a source of knowledge, but his deepest insights were grounded in the conviction that the common good was based on virtuousness, and that government and politics had their roots in moral philosophy and not in class conflict. ${ }^{3}$

Although Dieterici greatly admired Quetelet - in his letters he frequently addressed him as his 'maitre' - it is questionable whether they were in complete agreement on the nature and function of statistics. Even if they did agree that statistics was the foundation of good government, they must have realised that applying this idea to the Prussian and Belgian government systems and cultures would most likely lead to very different outcomes. In the nineteenth century, statistics was both a social science and an instrument of government. Nevertheless, every handbook opened with a different definition of statistics and every country had its own way of organising statistical research. The statisticians who gathered in Brussels in 1853 shared a boundless optimism and believed in the scientific neutrality of statistics, but when they tried to put their ideas into practice they encountered many obstacles.

Railway connections to Brussels were excellent. At that time, Belgium had the densest railway network in the world and Brussels was the main hub. International meetings were frequently staged in the city. In the period 18301850 Brussels and Paris were the refuges of exiles and political fugitives. In 1841, count David Fredrik Frölich, a lawyer and Member of Parliament from Sweden, had asked the Belgian government to support his initiative to establish an international peace society. The main task of the society, which he wanted to seat in Brussels, would be to collect and publish statistical data that had been 'subjected to philosophical assessment'. The Belgian Central Commission for Statistics, which was ordered to handle this request, decided that it was not possible at that time to integrate science and politics in the way Frölich proposed. ${ }^{4}$

Clearly, though, for many liberals Brussels occupied a central place in their mental map of Europe. In 1852 sanitary reformers, or 'hygienists', held their first congress there. A few weeks before the statistical congress, geographers, meteorologists and naval officers gathered there to discuss the state of the atmosphere and the world's oceans. The aim of that congress was to establish uniformity in meteorological and hydrographical observations made around the world.

Quetelet was in charge of that congress as well, and saw the obvious similarities between the two. Though statisticians were not concerned with air currents and gulf streams, the objective of their congress was no less comprehensive. Quetelet presented it thus at the official opening: 'to study, in another context, the fluctuations, the movements and the obstacles in modern society. ${ }^{5}$ 


\section{The first congress}

On Sunday 18 September the statisticians held a preparatory meeting. Quetelet addressed the newly arrived participants and proposed to start the sessions with a presentation by the various statistical offices. No one objected, since that is what was stated in the programme. However, the mood was not as harmonious as it seemed. It was clear to everyone that politics had to be kept at bay, but they sensed that domestic and international political relations would make it difficult to maintain scientific neutrality, a feature of statistics that they all held sacred. The sheer diversity in the methods of organising government statistics pointed to governing traditions and principles that could not easily be harmonised. The idea of an international congress was born during the Great Exhibition of 1851 in London, but the coup d'état by Louis Napoleon in France on 2 December 1851 and the international disagreement about Schleswig Holstein in the spring of 1852 delayed preparations for a year. From the start it was clear that it would be difficult to reconcile national interests and the pursuit of international statistics.

In his report Dieterici noted that the congress delegates representing the German state statistical offices were in agreement that the Belgian arrangement - a statistical office under the interior ministry but steered by a scientific central commission - was an imperfect solution. Dieterici and his colleagues put their faith in the primacy of bureaucracy and had doubts about the Belgian practice of 'allowing committees, associations, representatives and delegates, societies, municipalities and interest groups to negotiate everything. ${ }^{6}$ The differences between the respective political and administrative cultures of the two countries were obvious and keenly felt.

Leopold von Ranke, the great German historian who happened to be conducting archival research in Brussels at the time, placed this divarication in an even wider context, calling it a struggle between 'Roman and Germanic ideas.' In the domain of statistics, too, he wrote to his brother Ferdinand, 'the trend of Germanic consciousness has been deeper and more comprehensive than that of Roman consciousness. The Roman approach, which identified strongly with a linear idea of progress, could not easily accommodate the ideas of the Germans or some Britons for that matter. At the same time, Ranke continued, the Germans were likely to provoke outrage as they adamantly defended their positions, precisely because they were a minority voting bloc and realised that all they had going for them was the impact of their words. Conciliation was out of the question, but there was mutual respect.

Ranke doubted the utility of such confrontations. He saw throughout history an eternal, dialectical interaction of forces and counter-forces, and so he developed a special fascination for times of crisis. This led him to believe that people should express their ideas freely and could learn from each other, but that they should take their time. Development was impossible without exploring every possible relationship between divergent ideas. Ranke abhorred his positivist contemporaries' mechanical faith in progress. With barely concealed 
pleasure he wrote to his wife Clara that he had managed to undermine the younger congress participants' sense of their own worldly wisdom by positing some well-chosen paradoxes.

Ranke's name was on the official list of participants but he did not attend the sessions. He read about the discussions in the newspaper. At the urging of the Prussian mission, he had stayed in Brussels and, having spent some time scouring the archives and communing with the dead, he was determined to find out what opinions people were professing in the land of the living. He allowed himself the pleasure of attending the banquet King Leopold held in honour of the congress participants. He described to his wife the European luminaries he observed or, in some cases, spoke to. He noted that Lord Ebrington, a member of the British delegation, spoke fluent French, was filled with philanthropic desires and had grilled the aged, bald-headed, earnest, gesticulating Spanish delegate, Ramón de la Sagra. He listened while Jan Ackersdijck, a professor from Utrecht, held forth and finally took refuge in generalities about the welfare of mankind when he could no longer follow his own theories. Ranke was impressed by the cosmopolitanism of Karl von Czoernig, head of statistics in Austria, whose protracted stays in Venice and Dalmatia had helped him understand the complex reality of public administration in his own country. Ranke conversed with Professor Friedrich Von Hermann of Munich University, who was responsible for statistics in Bavaria. Through a colossal effort, the impact of which could still be read in his countenance, Von Hermann had achieved importance in the state and in the literature. According to Ranke, the fact that Von Hermann provoked such opposition in the debates underscored his intellectual prowess. Ranke was struck by the verbosity and remarkable stories of the ageing Louis Villermé, a member of the Académie des Sciences Morales et Politiques. And of course there was the omnipresent Adolphe Quetelet, the host, who Ranke considered to be more a man of the world than a scholar. His fellow countrymen, whom he referred to as the Northern Germans, were convinced that the entire congress would prove futile. ${ }^{8}$ We will become better acquainted with all of these men and determine whether the presentiment of Ranke's compatriots proved true.

At the official opening of the congress in the room where Belgium's Royal Academy of Sciences usually met, there was not a hint of uncertainty. The interior minister, Ferdinand Piercot, who was responsible for government statistics, attributed to statistics a key role in social progress and emphasised that it had been a persistent concern for the government since independence. The full-scale census of 1846 was proof of this. Methodological uniformity would further elevate the status of statistics and imbue it with international esteem as a reliable science of public administration. And that was not all. Piercot stressed that 'thus conceived, statistics would strengthen the bonds between nations and the sense of brotherhood and peace, which protect mankind from the resurgence of foolhardy national rivalries, would be deepened everywhere." Perhaps the minister was referring to the international tensions of recent years, which initially had caused the congress to be postponed. 


\section{Preparations}

The optimistic words of the Belgian minister echoed the idealism that rang out when the plan for a congress was first presented. Quetelet and Auguste Visschers launched the proposal at the meeting of the Central Commission for Statistics of 11 July 1851. Visschers, born in Maastricht, was a typical liberal reformer striving for a more compassionate world, beginning with better working conditions, fairer criminal law and more humane prisons. Science as the engine of progress: that was Quetelet's and Visschers' motto. The 'European family' would be the better for it: a meeting or even a permanent organisation would be established to carry out the studies that would be initiated on a joint basis. It would 'be to all of Europe what a central commission or a ministerial agency was to a single state'.

Quetelet and Visschers would not go so far as to anticipate 'the day when the states of Europe would have the same laws, the same institutions, the same currency and the same weights and measures', but they were certain that the increase in commercial and scientific contacts would inspire a tendency to copy the recognised improvements conceived in other countries. 'Instead of withdrawing into indolent egoism or clinging to old nationalities, science would organise general schools of thought', which would benefit all of humankind. If the Central Commission found its way clear to approve the proposal, the two initiators would go to the Great Exhibition in London to recruit members of the Statistical Society for the project. ${ }^{10}$

Quetelet knew that they would not encounter any resistance in London. He had been involved in the genesis of the Statistical Society of London, which was founded in 1834 to give the new statistical department of the British Association for the Advancement of Science a broader radius of action. Quetelet had been invited to attend the association's meeting in Cambridge in June of 1833 . He was there first and foremost as a representative of the Belgian Royal Academy, in which he played a prominent role until the end of his life (as permanent secretary from 1834 onward). But as an astronomer he could also join in the debate with authority. While in England, he took the opportunity to check data on magnetic forces that he had acquired on the Continent. In the report of his journey he also described various experiments and presentations he attended. ${ }^{11}$

Despite all this activity, his visit in the summer of 1833 would have gone virtually unnoticed had he not discussed his suicide and crime research with Richard Jones, a professor of political economy in London. The latter was intrigued and convened a meeting in his office at Cambridge to which he invited everyone involved in statistics. The seminar could not be part of the main programme because the assembled minds, most of whom were scientists, feared the political implications of the science of statistics. In those days, England was under the spell of a new poor law, which in turn was embedded in a gradual expansion of the state. Numbers may not have played a decisive role in the debates, but the proponents of reform were keenly aware of the power of statistical data. 
As the traditional political arguments rooted in philanthropy and paternalism receded into the background, the importance given to numbers grew. The figures from the annual poor relief statistics began to tell a story, 'the story of poor law "abuse", of maladministration, of rate-payers' misery, and of market distortions. ${ }^{12}$ In this climate the scientists were understandably loathe to venture outside their profession and openly join in the political debate.

It was therefore an extraordinary step for Richard Jones to assemble the statisticians, or those who considered themselves such, in his Trinity College office. Along with Quetelet the group included old Thomas Malthus, author of the influential Essay on the Principle of Population dating from 1798, Charles Babbage, a mathematician famous for inventing a tabulator, and William Whewell, a Cambridge professor, first of mineralogy and later of moral philosophy. Quetelet had met Babbage in Paris in 1826 and Whewell in Heidelberg in 1829 at a meeting of the Gesellschaft Deutscher Naturförscher und Ärzte.

Despite its curious beginnings, the initiative of Jones, Quetelet and the others was a great success. Within a year, they had established the Statistical Society of London, which is discussed in detail in Chapter 4. This chapter is concerned with Quetelet's key role. He was, of course, the Statistical Society's official correspondent. In Brussels in 1837 he had spent a year teaching the calculus of probability to Prince Albert of Saxe-Coburg-Gotha, who married Queen Victoria of Great Britain in 1840. Since that time, Albert and Quetelet had maintained a fairly regular correspondence. ${ }^{13}$ In 1846 Quetelet published a probability study in the form of letters to the prince and his brother Ernst. ${ }^{14}$ In 1860, when Albert opened the fourth international statistical congress in London, he lavished praise on his teacher.

When the Belgian initiative to hold a statistical congress in London in 1851 was discussed, it was greeted with joy and optimism, though Quetelet had probably not travelled to London due to illness. That Visschers could speak in his name was enough for the English and foreign visitors to the Great Exhibition. In November 1851 Visschers reported to the Central Commission, informing the members that he had informally consulted a number of foreign experts, such as George Richardson Porter, Joseph Fletcher and William Farr from Britain but also Horace Say and Joseph Garnier from the Société des Economistes, and had received only positive reactions. They proposed to hold the congress in September 1852. The programme would need to be set in advance of the congress. A provisional schedule of sessions was sent to the provincial statistical commissions and to foreign correspondents; in addition, official delegates would be invited through diplomatic channels.

The programme was divided into three sections. The first section would address how statistics was organised in the various countries; in addition this section would focus on the numerical description of the territory and population figures (censuses, registration of births, deaths and marriages, migration - the term 'demography' was not yet in common usage). The second section would concentrate on economic statistics (which the preparation committee considered to include 'workers' budgets'). The third section was intended for 
the presentation and discussion of statistics on the mental and moral condition of the people (poverty, schools, crime and punishment). This included the causes and effects of emigration.

Evidently, the search for a satisfactory division of tasks (and thus of the topics of statistical research) was still ongoing. In the spring of 1853 the time seemed ripe to start making preparations for the congress. The subcommittee, led by Quetelet and Visschers, had meanwhile revised the programme. The components concerning emigration were incorporated into the first section and the discussion of workers' budgets was moved to the third section. The Central Commission's concise reports do not offer an explanation of this revision.

The relocation of workers' consumption expenditure is particularly telling. What was at first an economic issue became a moral issue with a single stroke of the pen. Workers' budget statistics were highly sensitive. The state's role in alleviating poverty would eventually come up and was sure to spark a fierce political debate. This could explain the caution and uncertainty surrounding the subject, but we will see that other, seemingly neutral topics of statistical research were no less thorny.

\section{Belgians as trailblazers}

Belgium's pioneering role in the European statistical movement was informed both by its liberal polity and the special status of statistics within it, and by Quetelet's key position as an intellectual. By the mid-nineteenth century, under Quetelet's leadership a learning process had had an impact on government statistics in Belgium and many practical problems had been resolved. In 1846 a general census of population, industry and agriculture was held in every municipality. Quetelet and his colleagues gained a great deal of experience by conducting the survey and processing the data. In 1853 the Belgians were ready to receive Europe.

The organisation of Belgian statistics was in a way a legacy of the United Kingdom of William I, though it must be said that the heirs received a much higher return on 'capital' than most Northern Netherlanders had thought possible. After years of hesitation, in 1826 William I signed the Royal Decree establishing a statistical office and a statistical commission whose task was to coordinate the work of the office. The period after the fall of Napoleon and withdrawal of the French from the Low Countries had been an uncertain time for the field of statistics. Some ministries accumulated statistical data, but the information was not compiled systematically anywhere. In the provinces, some governors attempted to interest local elites in statistics. Some private individuals published certain statistics. At the universities, statistics was incorporated into the study of law and history, but to professors and students it was no more than a fairly insignificant subsidiary subject.

Those who took the subject of statistics seriously believed that publicity could ensure its future. Development would be impossible unless information 
about the country, the population and the economy was published. In 1819 the statesman and economist Gijsbert Karel van Hogendorp defined the function of statistics as follows: 'The true foundations of the Economy of the State cannot be generally known and accepted unless statistical pronouncements are made public, as this will concentrate minds, and cause everyone to reason and write about it until, eventually, a public opinion on the subject emerges that is conducive to general prosperity, and could overcome all opposition. ${ }^{15}$ The decision of 1826 was a tentative, overdue response to this implicit plea.

The statistical commission comprised the interior minister Pierre L.J.S. van Gobbelschroy, who hailed from the Southern Netherlands, and several administrative officers from his ministry. The key figure of the commission was the secretary, Édouard Smits, who would emigrate to the new state of Belgium with Quetelet in 1830. Not one to restrict his activity to his official tasks, in 1827 Smits published a commentary on the first series of tables issued by the commission. He embellished his commentary with an explanation of his vision on statistics. His ideas were anything but original. He pursued a synthesis of French political arithmetic and the German cameralistic tradition of the study of Staatsmerkwürdigkeiten, but produced no more than an unconvincing hodgepodge. From Joseph Fourier, who had contributed to the then highly esteemed Recherches statistiques sur la Ville de Paris et le Département de la Seine (18211829), he borrowed a definition of statistics as a science that was limited to facts concerning the power and wealth of the people. Following in the footsteps of the Historical School of Gottfried Achenwall and August Ludwig von Schlözer, he saw statistics as a link between the past, present and future. And as if that were not enough, he believed in the universal and eternal law of nature, which prescribed that the kingdom of the Netherlands was moving towards a state of social perfection, a process that the exertions of statisticians could only accelerate. ${ }^{16}$ Statistics was rich in pretention, but still deficient in application.

The commission's most important initiative was the census of 1829 in the United Netherlands. There were large and painful gaps in the existing population statistics. Without a precise population count, the statistics available were unusable. Civil servant and mathematician Rehuel Lobatto, who began publishing an annual containing interesting information about the country and its people in 1826, alerted the statistical commission to the deficiencies in the incomplete population figures, which were calculated on the basis of annual birth and death figures. Lobatto proposed to resolved the problem by holding a census every ten years, an idea that he had borrowed from one of Quetelet's earliest statistical publications, Recherches sur la population, les naissances, les décès, les depôts de medicité, etc. dans le Royaume des Pays-Bas (Brussels 1827).

\section{Quetelet in focus}

There are several reasons Quetelet's Recherches of 1827, a book of less than 70 pages, can be considered the key to nineteenth-century government statistics. 
Quetelet was thrust into the limelight as a social statistician, though arguably he could lay little claim to originality. His book addressed the condition of the population in the United Kingdom of the Netherlands. But in addition to the statistical project he discussed all kinds of related phenomena, such as fertility, mortality and birth rates in different months of the year and times of day. For example, the fact that in various parts of the kingdom the death rate bottomed out in July had to be significant, all the more so because Villermé had made similar observations in France. The ratios and averages that Quetelet observed led him to consider possible causes, but also to intuit that there were laws governing the incredible regularity of births and deaths. In his later work, Quetelet would expand this insight into the highly creative, but flawed, theory of the homme moyen, the average person. In the Recherches he was still very cautious and sought above all more and more reliable numerical data. With great subtlety he also conveyed a political message: population growth would be possible only if agricultural and industrial production were promoted and if the people were given an appropriate degree of freedom that would guarantee public confidence. ${ }^{17}$

The Recherches was an eye-opener for King William I and his closest ministers, though they saw in it something different than Quetelet's true intentions. The court regarded Quetelet as the man who, in accordance with the principles of eighteenth-century German cameralism, which was strongly oriented towards the state, could put the Netherlands on the map in the discipline of statistics, and invited him to write a paper comparing the vitality of the Dutch state with that of other states. Quetelet undertook the task, but the finished paper was published in 1829 by a private house and was not issued as a government publication. ${ }^{18} \mathrm{He}$ could not reconcile the power-politics ambitions of his patrons, who were thinking in terms of the enlightened monarchy, with his belief that statistics should benefit the public or with the high standard of reliability he required of the figures. The Recherches of 1827 pointed not to the past but to the future, and in a certain sense to a future that did not materialise until the twentieth century.

Like Lobatto, Quetelet saw the dire necessity of a new census. His education and practical training in mathematics and astronomy led him to a simple and revolutionary solution: it should be possible to count the entire population purely on the basis of the number of births (which was, as a rule, recorded with great precision in the births register), if one only knew which 'multiplier' to use. The multiplier could be calculated as follows. It begins with a careful selection of a small number of municipalities. For each of the municipalities, you determine the total number of births in a number of years and then calculate the variable by which those figures must be multiplied to arrive at the figure for the entire population in the relevant municipality in those years. The outcome is a multiplier that can be used for each region or country to quickly obtain an accurate population figure.

Quetelet derived the probability method underlying this calculation from French mathematician Pierre Simon de Laplace, who himself was indebted to 
the intellectual milieu of the Académie Royale des Sciences of Paris. Soon after the mid-eighteenth century, political arithmetic received a strong impulse in France. ${ }^{19}$ This method was grounded in the development of mathematics; financial considerations undoubtedly also played a role, but the decisive factor was the impossibility in eighteenth-century France of achieving a degree of precision in traditional censuses that would satisfy the scientists of the Académie Royale des Sciences. Despite the incredible efforts of academicians like Condorcet and Laplace to perfect the probability method and its application in public administration, the growing distance between the intellectual aspirations of scientists and the interests of the state after the French Revolution signified the temporary end of political arithmetic. By the time Laplace published his principal works (Théorie analytique des probabilités, Paris 1812, and Essai philosophique sur les probabilités, Paris 1814), sampling and multipliers were unknown quantities in government statistics.

The fact that Quetelet nevertheless proposed a census in 1827 based on the Laplace method had more to do with his background in mathematics and astronomy than anything else. In 1823 he had received a government grant to go to Paris and learn about astronomy and how to operate an observatory. Quetelet's biographers cannot say for certain whether he was taught by Laplace, but it is indisputable that Laplace had enormous influence in the circles in which Quetelet moved. In 1825, still focused on the idea of establishing an observatory in Brussels, Quetelet launched a scientific journal, the Correspondance mathématique et physique, with Frenchman Jean Guillaume Garnier, a professor of mathematics and physical astronomy in Ghent. Though the journal focused on the natural sciences, mathematics, engineering and astronomy, increasingly more space was given to social statistics and related commentary. In the first issue of 1825, Quetelet himself published the average number of births in Brussels over an eighteen-year period categorised by months of the year. The distribution, he noted, could be graphically represented by a sine curve, which we know as the normal distribution. ${ }^{20}$ From the various articles that Quetelet wrote on statistics, we can conclude that he presented his data and conclusions to recognised specialists, such as Villermé and Fourier. In addition to population statistics he began to study schools, crime and prisons. His interest in these areas was apparent in the Recherches.

The progress that Quetelet made in statistics around 1825 inspired him to propose a new census, based on the Laplace method. He must have had doubts, though, because he appended the commentary of Charles L.G.J. Baron van Keverberg van Kessel to his proposal. Keverberg was somewhat critical of the probability method, which was completely new to him. He did not believe it was possible to select a representative but limited number of municipalities that could do justice to the many aspects of the 'laws' governing birth and death. $\mathrm{He}$ cited the differences between urban and rural areas, rich cities and poor municipalities, densely and sparsely populated areas, and pointed to a whole spectrum of geographical circumstances. However, it was typical of the prevailing thought that he nevertheless referred to the 'laws' of birth and death. But the 
only way to determine how many people lived in the kingdom was to hold a full census, by which he meant lists of all inhabitants, stating their ages and occupations. ${ }^{21}$ Only in this way would it be possible to say anything sensible about the laws that governed shifts in the population.

It is no coincidence that Keverberg suggested this. Under French rule, he had been vice prefect of Kleef and under William I governor of Antwerp and later East Flanders. In 1817 in East Flanders he had led the establishment of an association that would coordinate statistics for the province. If there was anyone who was knowledgeable about the practical administrative side of statistics, it was Keverberg.

Quetelet allowed himself to be persuaded by the former governor, although the latter did not omit to stress the difficulties inherent in a large-scale census that would have to be overcome. The state would be dependent on census officials and local governments, which could not all be expected to be equal to the task. Unambiguous questions and thorough checks were therefore absolute conditions. During the French Empire, the state had overloaded the local governments with statistical circulars whose purpose was not always evident. Moreover, the political intricacies of the day were so complex that the interior ministry was unable to devote sufficient attention to the processing of data. Keverberg assured Quetelet that in the current circumstances it was to be expected that a well-structured statistical survey would be more successful. The lower levels of government stood to benefit from the data that they collected. They, too, needed to know what was happening in their territory in order to exercise the constitutional freedoms, however limited, they had acquired in 1815.22

Adolphe Quetelet would have thought long and hard about all these observations. When, in his capacity as chairman of the Central Commission for Statistics, he bore responsibility for the first census of Belgium as an independent state, he adhered meticulously to Keverberg's instructions. Apparently, Quetelet was easily dissuaded from his probability plan. He may have felt that he lacked sufficient knowledge of administrative practices and that Keverberg was a reliable authority. Moreover, he had no objection on principle to gathering large quantities of data. But what effect might it have had on government statistics and perhaps even the state if random sampling had been attempted at the beginning of the nineteenth century? The censuses and other large-scale statistical studies that European (and non-European) countries organised throughout the century strengthened the state like no other instrument of government. The masses had little contact with the state, paid no direct taxes and had no voting rights, but the census agents brought the state into their homes.

Quetelet was not intensely involved in the national census that was ultimately held in 1829. He continued to focus his attention on the observatory that he wanted to build in Brussels. In the autumn of 1827 he travelled to England and Scotland. In January 1828 he was made the official astronomer of the observatory, before construction had even begun. In the summer of 1829 he went abroad again, this time to Germany, where he met with many scholars and writers. 
The highlight of the trip was undoubtedly his visit with Goethe at his home in Weimar. Goethe was a famous all-rounder, who in old age remained intensely involved in the natural sciences, and morphology in particular. Goethe was envious of Quetelet, who would be attending the forthcoming scientific congress in Heidelberg, because he was anxious about the possibility of his work being subjected to scrutiny there. Like a novice, he insisted that Quetelet inform him about how his ideas were received at the congress. They discussed natural phenomena and the order that was apparent in them. They also talked about Goethe's optical theories. Until Goethe's death in 1832 they exchanged several letters in which Goethe was highly complimentary of Quetelet's wife, who had a hand in managing her husband's social life. ${ }^{23}$

Several decades later, Xavier Heuschling, Quetelet's close colleague at the Central Commission for Statistics, wondered whether Goethe's winged words, which many a statistician cited in his own writings, had been inspired by Quetelet's visit: 'They say that numbers govern the world, but it is certain that numbers show how the world is governed. ${ }^{24}$ Goethe's words did, in fact, date from after their meeting. However, they were prompted by less exceptional circumstances. Biedermann, who published Goethe's conversations, recorded these words as Goethe's reaction to an article in Le Temps about the income enjoyed by the English clergy, which was comparable to a good secular income, and as such provoked Goethe's disapproval.

\section{The average man}

Following the breakup of the United Kingdom of the Netherlands, the process of renewal that organised statistics had undergone after 1825 was completely undone. The statistical office and the statistical commission faded into obscurity. In Belgium, by contrast, government statistics began to gain momentum. The proclamation of the new state virtually coincided with the founding of a statistical office at the interior ministry. The Belgian constitution dates from 7 February 1831; the decree establishing the statistical office dates from 24 February of the same year. The new state began issuing official statistics publications almost immediately: in 1832 Quetelet and Smits published the Recherches sur la reproduction et la mortalité de l'homme aux differents âges et sur la population de la Belgique, a year later the Statistique des tribunaux de la Belgique. Other government agencies reported their annual figures, too: on foreign trade, urban excises, justice, land ownership, mining and industry. The young liberal state sought information to affirm its existence and steer its government and the people wanted information that would enable them to exercise their freedom to the fullest extent. It gradually became clear that a degree of uniformity needed to be injected into statistical research for it to remain significant to the state and the public.

To that end, a Central Commission for Statistics was established in 1841. The commission's remit was to homogenise national statistics, in part by detecting 
lacunas, suppressing superfluous details, creating uniform tables and introducing a clear classification system in published statistics. The chairman of the commission was, of course, Adolphe Quetelet. Most of the other members were representatives of government ministries. In 1843 special commissions were set up in every province. Each of these commissions was chaired by the governor of the province, and was given the task of promoting statistical research at provincial and local level and checking raw data before it was sent to higher authorities.

In the meantime, Quetelet had solidified his reputation as a statistician. The first edition of his Sur l'homme et le développement de ses facultés, ou Essai de physique sociale appeared in 1835. It synthesised the whole of his work on social statistics to date. It was the zenith of his search for the laws of society. His goal was to create a new science - social physics - which was concerned with population issues, education, crime, industry and agriculture. It would be a science that made the task of the legislator easier: in today's parlance, it was a policy-relevant science. Quetelet appears to have been unaware of the fact that Auguste Comte had already coined the term 'social physics' to describe the allencompassing science that he had envisaged. Out of desperation, Comte decided to call his science 'sociology', though he doubted the name would stick.

The great appeal of Quetelet's book lay in the metaphor of the average man. The concept must have captured the imaginations of the denizens of the nineteenth century. It was an idea that soon broke free from its originator's intended meaning. In the same way that Musil's 'Mann ohne Eigenschaften' seemed to capture the essence of twentieth-century man, 'l'homme moyen' represented his nineteenth-century predecessor. Because Quetelet's statistical thinking was grounded in his knowledge of astronomy, he saw in all numerical observations regularity and - above all - an orderly clustering around averages. From his studies in astronomy he understood the notion of the normal distribution, a special kind of frequency distribution that astronomers use to determine the position of celestial bodies. The so-called Gaussian distribution or bell curve is the graphical representation of the normal distribution. In the same way that astronomical observations tend to cluster around the precise position of the stars, sets of physical and moral characteristics of human beings tend to be concentrated in the average person.

'The average man', Quetelet wrote, 'is to a nation what the centre of gravity is to a body; all manifestations of equilibrium and movement can be estimated on that basis. ${ }^{25} \mathrm{He}$ gave examples of physical characteristics, such as weight and girth, but the most interesting were of course the moral characteristics of human beings, which if sufficient observations were made would always point to an ideal, average value. In a later work, Quetelet noted: 'For his moral abilities, like his physical abilities, man is subject to minor and major deviations from an average; the variations around this average follow the general law that determines all the fluctuations which a series of phenomena can undergo under the influence of coincidental causes.26

The average man was, in a sense, also a perfect man. Quetelet believed that 
the progress of civilisation was evident from the closing gap between the highest and lowest values by which human behaviours could be expressed. This was also at the root of Quetelet's anti-revolutionary stance: in situations of equilibrium, revolution was unnecessary and even impossible. In 1830 and even more so in 1848 he tried to steer clear of every form of radicalism. His measured attitude appealed to like-minded individuals who were more closely engaged with political reality.

Vincenzo Gioberti, an Italian nationalist who took inspiration from his Christian faith, wrote to Quetelet from Paris in February 1848, at the height of the riots in the French capital. They knew each other from Gioberti's years of exile in Brussels. Gioberti had just read Quetelet's latest book, Du système social, and was deeply affected by the political philosophical wisdom articulated in it. The popular fury and devastation in the city filled the Italian priest with dread. If Louis-Philippe's government had been more mindful of the average man, he wrote, then revolution could have been averted: 'If Louis-Philippe and his wretched ministers had thought about the average man, then they would not have blindly hurled themselves into a system that is precipitating their downfall and may bring great misfortune to France. I have committed myself to rereading and studying your book. I believe that an entire political system can be built upon it. ${ }^{37}$ Quetelet was first and foremost a man of science and distanced himself from explicit political positions. His average man was much more than an engaged citizen.

The perfection that Quetelet saw in the average man was not always easy to explain. After all, it was not just the positive characteristics of people that tended towards a single point, but suicidal and criminal tendencies could also be reduced to average values. Quetelet's article on 'le penchant au crime' dating from 1831, which he paraphrased in his Sur l'homme, stoked some controversy. He was so astonished by the regularity that he saw in crime statistics that he seemed to be saying that every human being was inclined to evil. Every year produced virtually identical totals in the various categories of crime. Obviously a disposition to crime did not conform to the standards of decency of the bourgeoisie, but Quetelet pondered an entirely different explanation of his observations. He was particularly interested in the circumstances that influenced crime, such as climate, seasons, sex, education and, above all, age. If only one could acquire a good understanding of these factors, it would be possible to conceive of ways to suppress the tendency.

Without expressing himself explicitly in political terms, he indicated how the state could employ its resources. Member of Parliament Henri de Brouckère referred to Quetelet in his plea to abolish the death penalty and to take alternative measures during the session of 4 July 1832. Crime statistics were similar from year to year, as was public spending to combat crime and punish convicted offenders. Increasing state expenditure would no doubt have a positive impact on the crime rate. De Brouckère was summarising Quetelet's ideas when he said that crime and punishment were ultimately budgetary matters. ${ }^{28}$ While the inclination to commit crime may be a general human trait, it does 
not necessarily follow that it is immutable. Eliminating certain causes could keep some effects at bay, thus reducing crime, expenditure and inconvenience. In other words, the political counterpart to the notion of the average man was a deep desire to exercise control.

The average man was not a coherent concept in every respect. Quetelet recognised that the measurability of phenomena depended on the 'population'. In the definition from Sur l'homme (1835) cited above, he spoke of the nation as the territory of the average man. However, a population was, in theory, even larger. The precision of the average increases as the series of observations expands. According to Quetelet physical characteristics, for example, have not changed throughout the history of humanity, and are therefore most recognisable when the measured group is at its largest. His dream of an international statistics was born of the conviction that everything that could be counted should be counted. On the other hand, he also wrote that the average man is defined by place and time, and that society is not an instrument for men to manipulate at will so that it produces the desired statistical results. In the view of his biographer, Frank H. Hankins, Quetelet did not actually consider this paradox fully. ${ }^{29}$

Others believe that there was no inconsistency and that Quetelet did not seek 'simple', physical laws. According to Stephen M. Stigler, he was fully aware of the complexity of social life and, in fact, wanted only to accumulate as much data as possible and, from that data, distil different categories of causes. If too few causes were identified, mistakes would be made and it would be impossible to discover laws. ${ }^{30}$ With Quetelet, it is difficult to separate the ends from the means. Reason took him a long way but did not utterly dominate his thinking. He looked at people the same way he looked at the stars: from a distance. His visions of the concentrated order and of the average man added an extra dimension to his logic: if one could only collect enough data, all diversity would amalgamate into an average, a brilliant focal point. He was blinded by that brilliance. For Quetelet, the truth lay in the middle and nowhere else.

\section{Counting in Belgium}

When the Central Commission for Statistics was set up in 1841, no one but Quetelet, by then an internationally renowned statistician, could have been chosen to preside over it as chair. In 1838 his Sur l'homme had been translated into German and supplemented by a doctor from Stuttgart, V.A. Riecke. R. Knox, a Scottish doctor, would produce an English translation in 1842. It is no coincidence that both translators were doctors. As we shall see in later chapters, doctors were important actors in the statistical movement. The medical profession was also represented in the Central Commission. Dieudonné Sauveur, inspector-general of the health service and permanent secretary of the Academy of Medicine, was a member for nearly as long as Quetelet himself.

The commission's first major task was to supervise a census of Brussels in 1842. It was obvious to everyone that this was to be a test run for a general 
census of the entire Belgian population. A national census was the largest statistical lacuna in the young state. In the first part of the Bulletin de la Commission de Statistique, Quetelet discussed the Brussels census in detail. The figures and the technical details concerning the implementation were the most important, but Quetelet got carried away with the order he detected in the numbers. First, following Villermé, he studied the city in terms of specific characteristics, such as quality of housing, and then discovered to his surprise that the best districts were the least industrialised, or that income was highest in the parts of the city where the most foreigners lived, 'as if change in the make-up of the population is an element of vitality and prosperity'. It seems that he was really surprised by his own observation that 'the grouping of urban districts by size and quality of dwellings can be seen in a new light if one takes into account that this grouping is inversely proportional to that of the residents in the poverty register?' The conclusion was almost too obvious: 'The results are mutually verifying and provide the ultimate guarantee for the care with which the count was carried out. ${ }^{31}$ Heuschling, the secretary of the commission, went a step further in his interpretation of the data on Brussels. He delved deeper into the relationship between occupational groups and rates of birth out of wedlock, which to his apparent astonishment were highest among domestic workers and day labourers. He also noted that in the case of illegitimate births, the percentage of girls was higher than that of boys (while this was normally the other way around). $\mathrm{He}$ concluded from this that 'as previously observed, illegitimate unions appear to be an obstacle to the further development of the male population. ${ }^{32}$ Such categorical conclusions reflect the moralistic undercurrent that pervaded the interests of statisticians, and more generally the anxieties of the moneyed middle classes. That said, statisticians were not overt moralists. It is necessary to read between the lines of their texts and tables and distil their underlying thoughts indirectly from the categories and classifications they employed.

The outcome of the Brussels census was encouraging and reinforced the conviction held by Quetelet and his colleagues that the time was ripe for a national population census. On 28 July 1843 the commission composed a report for the interior minister, which was also published in the Bulletin. The report stated that annual population figures were still being based on the count of 1829. The commission suspected that the municipalities were fiddling the numbers to limit the number of militia conscripts. But the liberal state required a precise population count for many of the public bodies that were prescribed by law. For example, the size of the municipal council and some court juries and certain tax rates depended on the number of inhabitants. 'The process of counting and registering the population was an essential component, in fact a sine qua non, of liberal government in the Kingdom of Belgium. ${ }^{33}$

The central state had an ambivalent role: on the one hand, it was the highest manifestation of the concepts of freedom and representativeness, on the other, the state was compelled, not least when conducting statistical research, to intervene vigorously in social life. The commission emphasised the importance of top-down control: 'Government intervention is essential to adequately guarantee 
the fairness of the count; if we want the count to accurately reflect reality and wish to prevent local authorities from lowering the population figure at will, as they have done in the past, the results must be adequately verified by a higher authority, which in case of doubt as to the precision of the figures obtained will be duty bound to take appropriate measures and, if necessary, order a new count. ${ }^{34}$ Clearly, statistics presupposed an active state, though at first glance this appears to contradict the principles of early nineteenth-century liberalism.

Quetelet also emphasised the scientific importance of the census. Regarding the Brussels census of 1842 he wrote: 'It is not enough ... to know a population's quantitative strength. We must also analyse the elements of which it is composed. This analysis will enable us to determine the degree of prosperity, the strength and the needs of that population and form a fairly accurate notion of its future. A population count has more than an absolute value; the population figure is the indispensable element to which we must turn to estimate the mortality rate and find solutions to all manner of problems concerning medical statistics, government and public administration. ${ }^{35}$

The great census of 1846 shows what effects Quetelet's ideas had in practice. The members of the commission had been working unremittingly on the preparations since 1843. They accumulated the data from the population counts that had been performed within Belgian territory since 1801. They asked the provincial statistical commissions to give their views on how a national census should be held. A myriad of problems presented themselves: whether to count the actual or legal population, distribute census cards per family or per dwelling, monolingual or bilingual cards, how to distinguish the uses of different parts of a house, how to specify the extent to which people depended on poor relief, age and place of birth, degree of sanguinity, language, faith, occupation, etc. The commission also asked the provinces to discuss changing the house numbers, how census agents would perform their task and how information should be extracted from the cards, while it applied itself to the agricultural and industrial censuses that would be conducted simultaneously.

Once the commission had considered every detail, secured a budget from the interior ministry and drafted provisional regulations, another trial count was conducted, this time in Molenbeek-Saint-Jean, covering not only the population but also agriculture and industry. From this test run, the commission concluded that the structure was effective, but consideration would need to be given to popular fears that the primary aim of the exercise was to raise national taxes. On 30 June 1846 the king signed a decree ordering a census of the population, industry and agriculture to be held on 15 October of the same year.

During the period between 30 June and 15 October the commission did not leave the country in peace. On 13 July it had the ministry send out a circular to the governors calling on them to convene meetings of the provincial statistical commissions, district commissioners and mayors. The ministry would send representatives of the central commission to the meetings. The commission's goal was to eliminate every risk of unforeseen problems interfering with the execution and processing of the census. Commission secretary Heuschling put 
together a programme of excursions to the provinces for the members. At the end of August, the central commission presented the ministry with a report on the results of these information-gathering visits. The remuneration of the census agents and others who were involved in the processing was an important point of discussion. Quetelet and Heuschling pointed out that agents working in the countryside would have to travel long distances and fill in large numbers of census cards themselves because many of the residents could not read or write. The ministry acknowledged the problem and approved a higher fee than had been originally planned. In September, circulars and letters were sent to the governors and various ministries to clear up any remaining questions and issue a few last-minute instructions.

The preparation demonstrates how deeply the operation affected communication between the various levels of government and, in general, between the state and society. The central commission liaised between the ministries involved and the provincial and local governments. The provincial statistical commissions, in which the local elites were strongly represented, provided local support. In the process, the census became an act of national integration.

Contact between the state and the population had never before occurred on such a massive scale. Census cards were delivered to each household a few days before 15 October 1846. Nearly 11,000 cards (plus the forms for agricultural and industrial organisations) were distributed in the city of Bruges alone. ${ }^{36}$ The city council appointed ten agents to distribute and retrieve the cards. All of them were municipal employees and this gave them an opportunity to earn a little extra. The governor monitored the procedures very closely and answered the city council's questions in writing. There was a never-ending stream of questions about details. Many people were not considered part of the 'ordinary' population (such as those residing in mental institutions, hospitals, military barracks, prisons, etc.) and the instructions did not cover every eventuality. It took the ten census agents seven half-days to distribute the cards. They were accompanied by police officers.

The municipal executive anticipated that the task of collecting the census cards, for which the royal decree of 30 June prescribed a ten-day period, would pose bigger problems. It was thought that the agents would have to fill in twothirds of the cards themselves. The agents began their task before the day of the actual census, so that they would only have to check the information on or around 15 October. This was not entirely in keeping with the rules, but the municipal council saw no alternative. In a municipal order issued before the distribution and collection of census cards began, the agents were instructed to start their day at half past eight in the morning; they could break for lunch at half past twelve but had to return to their regular jobs by three o' clock. This schedule turned out to be overly optimistic. Collecting the cards in time demanded an all-out effort. On 4 November the municipal council of Bruges dispatched 10,821 completed and verified cards, in 95 parcels corresponding to the 95 districts in the city, to the governor for further processing. Each parcel contained a list of house numbers, a list of the corresponding census card numbers and a 
reckoning of the number of people residing in each dwelling.

The other municipalities of Belgium were no less industrious than Bruges. On 10 November, all the census cards were handed over to the provincial authorities. The members of the central commission continued their inspection tours to oversee the processing phase at first hand. On 23 December, Quetelet reported the first authorised results to the minister. Though he could provide only a total population figure for men and women at that time, his tone was irrepressibly elevated. He was deeply convinced of the central commission's mission in the operation. It was as if the words of Luke 2:1 - 'In those days Caesar Augustus issued a decree that a census should be taken of the entire Roman world' - were on his mind. He remarked again on the colossal efforts of the authorities and the population. His words were almost inadequate: 'Persons of every age and both sexes, native born and foreign, who were present on the day of the census were counted at the place where they passed the night.' He examined the methodology and came to the conclusion that the first Belgian census was among the best in the world. ${ }^{37}$ Heuschling wrote to Quetelet that the government should make the most of this success, since such comprehensive and rapid administrative results were rarely achieved. ${ }^{38}$

The prospect that from 1 January 1847 local authorities would be required to keep up-to-date population registers only increased the enthusiasm. The census cards would be returned to the Belgian municipalities, which would then be required to set up population registers based on them. This may have been the climax of the census for Quetelet and his colleagues. The households occupying permanent dwellings in the municipalities would be recorded in the registers and special registers would be established for the others. The authorities were most attentive to the advantages of being able to monitor the whereabouts of the 'dangerous classes'. Moreover, 'lawful domicile', a term from the civil code, now had an administrative basis. The statisticians hoped that this would enable them to continually monitor the human universe. To Quetelet, the population register was a microscope on society comparable to the telescope in his observatory that gave him a view of the stars.

\section{The statistical agenda in $\mathbf{1 8 5 3}$}

Given their value to statisticians, it is no wonder that the implementation and refinement of the census and population registers was an important item on the agenda of the international statistical congress in Brussels. In the congress programme that was dispatched in the spring of 1853, the census was high on the list of discussion topics, second only to the organisation of statistics in general.

In a brief address, the Belgian central commission presented the primary differences between censuses in European countries and in the United States. England and Belgium tallied their actual populations: every person who had spent the night before the census at the dwelling in which they were found was counted. France, Austria, Piedmont and the states of the German Zollverein 
employed a mixed system in which the actual and legal populations were enumerated. The commission favoured the actual population method, but proposed to leave open the possibility of registering the legal population as well. Rarely did any two countries hold their censuses in the same month or employ the same system of periodisation. The commission proposed setting 31 December 1860 as the next census date, followed by a new census every ten years. December was the month in which German states conducted their surveys and it seemed well chosen, since it was the time of year that people were least itinerant and the 'floating population' was smallest.

The commission had a preference for census cards by household, according to the Belgian system instead of a list by municipality, as in France. In their view, the major advantage of the Belgian method was that people filled in their data themselves, though occasionally under the supervision of government officials. In addition, the household census cards provided varied information, which would be easier to use for other purposes.

The matter of the census agents also required special attention, because the success of counting operations depended strongly on them. In most cases, local governments were responsible for appointing agents. In Württemberg, the local authorities called upon the clergy to assist; in France, they enlisted tax officers; in big cities, the authorities often engaged the help of visitors to the poor or other relief workers. By hook or by crook, the census agents had to make sure the information was filled in properly or complete the forms themselves 'in accordance with the instructions they were given'. Sensibly, the matter of payment was not addressed. The commission concluded with a proposal to formulate a minimum number of fixed questions on matters such as language, religion, occupation, income, illness and disability, and called for every municipality to create a population register to record all movements of the population.

How did the congress respond to this laundry list of preferences, which could have far-reaching effects on statistical practice? The printed report of the discussion is concise. Some of the participants, such as Horace Say of France, were of the opinion that information collected by means of a census should not be too detailed. For example, there were moral and practical reasons not to ask all kinds of questions about illnesses. Say caused some hilarity when he remarked that he found the question on abnormalities of the spinal column, which was inspired by medical debates on the influence of nutrition, climate and physical environment on that part of the body, a rather delicate one. He feared that at least half of humanity would appear in a bad light if questions were asked about physical aberrations of this nature. His countryman Joseph Garnier added that no one would want to interrogate a lady about physical defects.

Disagreement arose in the French camp about the penalty for refusing to furnish requested information. Alfred Legoyt, the head of France's census bureau, the Statistique Générale de France, favoured setting a penalty. Say opposed this idea, opining that people should not be forced to answer questions, as that would only serve to increase their suspicion. Quetelet did not want to 
attach too much importance to the issue of sanctions and steered the congress to reject Legoyt's motion. ${ }^{39}$

Notably, Dieterici's report of the discussion contradicts the printed proceedings of the congress. The proceedings are probably based on what was said during the plenary sessions and what was recorded in La Moniteur Belge, the Belgian Bulletin of Acts, Orders and Decrees; according to Dieterici, the gazette was somewhat selective. He noted in his report that he himself and the other Germans spoke frequently and defended the census method used in the Zollverein: 'Belgium, France and England may reckon as they like, but in my opinion the method employed in the Zollverein is correct and good. ${ }^{40}$ Dieterici wrote to his minister that he had strongly endorsed a three-yearly census because of the rapid pace of population growth in the German states. On this point, Quetelet abandoned the central committee's preference and took the position that the state should hold a census at least once every ten years.

Dieterici found the issue of language somewhat problematic, since he knew that German Poles understood and spoke both their mother tongue and the national language. But Quetelet did not want to dismiss this issue, because it was so important in Belgium. The census of 1846 showed that the majority of the population spoke 'Flemish'. According to Dieterici's summary of Quetelet's remarks on this subject, this finding was significant for the identity of the Flemish people.

With regard to illness and disability, Dieterici's preference was considerably more conservative than the proposal put forward by the central commission. The blind, deaf and mentally disabled could be counted, but dementia needed to be dealt with more carefully, since it was sometimes brought on by ageing and posed no risk or problems outside the household. It was undesirable to count kyphotic or crippled people or amputees. Dieterici was of the opinion that registering these abnormalities was not in the state's interests and, moreover, would demonstrate a lack of humanity. Austrian representative Karl von Czoernig supported his Prussian colleague and remarked drily that counting the number of people on crutches could affect entire villages. The final resolution was more moderate than the proposal: the survey would be restricted to blindness, deafness, mental disability and dementia.

Debates of this nature were frequent during the sessions held between 19 and 22 September 1853. Scientific objectives, state interests and social circumstances provided continuous food for discussion. The participants were well aware of the fact that the resolutions adopted by the congress merely reflected the preferences of the majority of attendees, and that no sanctions could be imposed for non-compliance with those decisions. The discussion concerning the organisation of government statistics made this abundantly clear. How could statisticians compel their governments to establish a central commission for statistics, comprised of expert civil servants and scientists, as proposed by the Belgian organising committee? According to the printed report, the congress skirted the thorny aspects of this issue.

Joseph Garnier, the official rapporteur on this subject, mentioned that con- 
sensus proved unattainable in the preparatory discussions held prior to the plenary session. The participants were unwilling to go further than recommending the establishment of a central 'institution' that would promote statistical research and operate independently of government bureaucracy but in contact with local authorities. The congress was disinclined to make an official pronouncement on this matter and restricted itself to adopting a resolution stating that every country should designate a person or body to see to it that foreign and domestic statistical publications were disseminated.

Dieterici's report reveals that there were deep differences of opinion. In his view, the central commission's proposal was predicated on the situation in Belgium and France. Quetelet himself, Dieterici emphasised, was an obvious example of a scientist who had avoided bureaucratic spheres until well into his career. This was also true of Legoyt and of William Farr, coordinator of the English censuses and a doctor by profession. Dieterici observed that these men were prominent scientists but not civil servants in heart and soul. In Prussia, statistics was imbued with the primacy of bureaucracy. Friedrich von Hermann of Bavaria and Czoernig of Austria concurred with him. Dieterici believed that in his fatherland everything could remain as it was. A central commission à la Belge' was completely unnecessary because the head of the Prussian statistical office already embodied the union of government and science. Both he and Johann Gottfried Hoffmann were professors of political economy in Berlin. Heuschling, the secretary of the Belgian central commission, supposedly told him in confidence that the commission had been set up primarily to convince parliament that it was safe to earmark funding for statistical objectives.

It is by no means certain that Quetelet would have endorsed this view. $\mathrm{He}$ was, after all, a man inclined to compromise. Throughout the congress, he played the role of the mediator, and tried to avoid insurmountable differences of opinion. The central commission's proposal to survey the working class was a sensitive issue. It was an initiative of Auguste Visschers, who explained his proposal to the assembly. In addition to his membership in the central commission, Visschers had a seat on the Mining Council and was well acquainted with the social impact of industrialisation. It was undoubtedly clear from the start that this topic would be a controversial one. There was a serious risk of a politico-ideological debate ensuing about the role of the state in social life. Visschers readily admitted that the plan to map the spending habits of the working class on the basis of questionnaires would usher in a new age of statistical practice. Once the public authorities had officially recognised statistics, 'people would feel the need to go further, to plumb the depths of the social order, with the aim of researching everything of importance to the political community or the circumstances of its members, particularly those who are exposed most to suffering and deprivation. ${ }^{41}$

Visschers made reference to England where, he claimed, research into workers' circumstances had originated. His proposal was based on a suggestion posed by the recently deceased school inspector Joseph Fletcher. Fletcher had done a great deal of work for the Statistical Society of London, studying the living 
standards of weavers, the spread of crime and, of course, the moral advantages of common education. Surveys of the working class had indeed been held in England since the 1830s. Visschers learned that government was not always the best-equipped institution to study workers close up, and that it was better to have intermediary agents carry out the task, armed with a list of clear questions. In Belgium, he had commissioned approximately one thousand interviews. Though not all the results had been processed, they gave an impression of the valuable information that could be obtained by this method. Visschers wanted to encourage statisticians from other countries to launch similar studies to gauge the effects of various physical-geographical and economic situations. At the end of his speech, he revealed that some state intervention was desirable to alleviate the direst need. Some schools of economic thought, he said, were too indifferent to the poor; others proposed dangerous systems. Entirely in the style of reformist liberalism, he exhorted his listeners to 'discover the truth' and act accordingly.

The debate on the proposal barely touched on the formulation of the survey questions but, as was to be expected, focused on the underlying ideas. Horace Say objected to being accused of indifference as an adherent of Adam Smith. He simply believed that it was unnecessary for every initiative, including the organisation of statistical research, to come from government. Visschers hastened to add that he had no desire to discredit anyone and was merely searching for solutions to a social problem. The congress decided to approve the questionnaire, but could do no more than recommend that those present adopt the programme put forward by Visscher and his colleagues. The results would then be compared at a subsequent congress. It will come as no surprise that it proved difficult to get this item put on the agenda.

Other topics, such as crime statistics, foreign trade, poverty, education and emigration, were hardly less controversial. There was a relationship between all these and the social tensions fostered by industrialisation, urbanisation and impoverishment. Statisticians believed they could tackle these problems scientifically and impartially. But as it turned out, it wasn't that simple. Most of the issues were politically charged. Charles Babbage, an indefatigable inventor, submitted a paper on lighthouses, which was one of the very few contributions that could be considered neutral. He was designing a system that would make it possible to allocate a unique light sequence to every lighthouse in the world. His paper was more appropriate for the congress of meteorologists and hydrographers that preceded the statistical congress, but it was nevertheless published as an annexe to the Compte rendu des travaux du congrès général de statistique. It reflected the statistics community's desire for precision and control, but what was possible for inanimate objects remained a utopia for social statistics. At the time, though, few statisticians realised this.

In September 1853 Brussels was for a short time the centre of statistics. Quetelet's charisma drew all the distinguished statisticians of the day to the Belgian capital. As a small, independent, liberal country, Belgium was the ideal place to host a 
gathering of scientists. But statisticians had aspirations that reached beyond science. Statistics was traditionally concerned with Staatsmerkwürdigkeiten: in the eighteenth century, the primary goal was to reinforce the power of the state and in the nineteenth century, there was a gradual shift in emphasis to improving the lot of the state and its people. The aims of statistical research varied from surveying human and economic potential to increasing the state's understanding and control of the dangers that threatened society. Examples of this will be discussed in later chapters. With such ambitious goals, statistics acquired a political mission that transcended the theoretical.

This burden weighed heavily on the international statistical congress. After Brussels, the statisticians wanted to move on, but the limitations were selfevident. They were unable to agree on the location of the next gathering. Berlin was mentioned, but Dieterici wouldn't commit himself. Legoyt, not wanting to be left behind, pointed out that Paris would be hosting the next World's Fair in 1855 . This presented a good opportunity to bring the statisticians together. The choice was ultimately up to the Belgian central commission. After the congress in Brussels, Quetelet asked the éminence grise of science, Alexander von Humboldt, for his opinion. According to Humboldt, a long-time resident of cosmopolitan Paris, Berlin was less suitable for international meetings. Perhaps his opinion was decisive for Quetelet. The second congress would be held in Paris.

Most statisticians firmly believed in the possibilities of their branch of science. Unlimited statistical research had many allurements. The illusion of increasing precision was one of them. Quetelet's metaphor of the average man reflected the false certainty harboured by statisticians in the mid-nineteenth century. They all shared a desire for uniformity and a boundless confidence in the future. This optimistic view of statistics was typical of the times. Around 1850 , the scientific world experienced a series of revolutions that heralded the birth of modern science. It was the time of Comte, Marx, Darwin, Charles Lyell, Justus von Liebig and many others. One of the main features of the transition was the use of mathematics, which consequently became a universal language. ${ }^{42}$ Mathematics was also a highly useful language for statisticians, though government statistics rarely required them to use methods of calculation other than addition, subtraction and averaging.

Faith in numbers or, more precisely, series of numbers had major consequences for bureaucratic practice. For a state to compile its statistics in compliance with the preferences of the international statistical congress, it had to be more 'involved' than was customary. This probably came easiest to the Prussians. It was a simple matter for an authoritarian, bureaucratic state to become a statistical state. In a sense, Belgium had a much more difficult road to travel. There was widespread agreement among political and government elites concerning the importance of statistics to the liberal state. They wanted to conduct statistical research in an environment of openness and public debate. That meant that the state would have to take on the complicated task of creating the institutional and social conditions under which usable statistics could be produced. 
In 1853 the belief in scientific progress was stronger than the perception that the realities of politics and bureaucracy could stand in the way of progress. Even Dieterici, who we have come to know as more of a realist than the other participants, decided that despite his low expectations the first international statistical congress promised well: 'The ethical awareness of the progress of the nations, yea of all humanity, through prosperity and moral persuasion, in other words the principle of a noble humanity, dominated the gathering, as divergent as the participants were in their country of origin, religion or personal position in life.' ${ }^{43}$ Most of the participants of the first international statistical congress left Brussels with a comparable sense of optimism. They were set to continue their journey of discovery.

\section{Notes}

1 Geheimes Staatsarchiv Preußischer Kulturbesitz (hereafter GStA PK), I. Hauptabteilung, Repositur 77, Ministerium des Innern, Abteilung I, Section 13, Nr. 99, Bd. 1 Statistische Generalversammlungen des In- und Auslandes (1853-1859), Report of Dieterici to the Ministry of the Interior, Berlin, 17 October 1853. The description of Dieterici's journey is based on this official report.

2 Ibid.

3 (C.)W.(F.) Dieterici, Über preußische Zustände, über Arbeit und Kapital. Ein politisches Selbstgespräch seinen lieben Mittbürgern gewidmet (Berlin and Posen 1848), VII.

4 Bulletin de la Commission de Statistique 1 (1843), 470, minutes of the session of 22 September 1841.

5 Compte rendu des travaux du congrès général de statistique réuni à Bruxelles les 19, 20, 21 et 22 septembre 1853 (Brussels 1853), p. 23.

6 GStA PK, Report of Dieterici, 17 October 1853.

7 L. Von Ranke, 'An Ferdinand Ranke (Hannover, 24 September 1853)', in B. Hoeft and H. Herzfeld (eds), Neue Briefe (Hamburg 1949), p. 358.

8 L. von Ranke, 'An Clara Ranke (Brussels, 22 September 1853)', in W.P. Fuchs (ed.), Das Briefwerk (Hamburg 1949), pp. 373-374.

9 Compte rendu à Bruxelles 1853, 19.

10 Bulletin de la Commission Centrale de Statistique 5 (1851), 23-25.

11 Correspondance mathématique et physique 8 (1835), 1-18.

12 D. Eastwood, 'Rethinking the Debates on the Poor Law in Early Nineteenth-Century England', Utilitas 6 (1994), 112.

13 E. Gossart, 'Adolphe Quetelet et le prince Albert de Saxe-Cobourg (1836-1861)', Bulletins de l'Académie Royale de Belgique, Classe des Lettres et des Sciences Morales e Politiques (1919), 211-254.

14 A. Quetelet, Lettres à S.A.R. le duc régnant de Saxe-Coburg et Gotha, sur la théorie des probabilités, appliquée aux sciences morales et politiques (Brussels 1846; in 1849 the letters were also published in English).

15 G.K. van Hogendorp, Bijdragen tot de huishouding van staat in het Koninkrijk der Nederlanden, ed. J.R. Thorbecke (Amsterdam, 2nd edn, n.d.) IV, p. 175.

16 É. Smits, Nationale statistiek. Ontwikkeling der een-en-dertig tabellen ... (Brussels 1827).

17 A. Quetelet, Recherches sur la population, les naissances, les décès, les depôts de medicité, etc. dans le Royaume des Pays Bas (Brussels 1827), p. 68.

18 A. Quetelet, Recherches statistiques sur le royaume des Pays-Bas (Brussels 1829).

19 E. Brian, La mesure de l'État. Administrateurs et géomètres au xviiie siècle (Paris 1994).

20 Correspondance mathématique et physique 1 (1825), 16-18. 
21 The mathematical implications of Keverberg's proposal are discussed by S.M. Stigler, The History of Statistics. The Measurement of Uncertainty before 1900 (Cambridge, MA and London 1986), pp. 163-169.

22 Quetelet, Recherches sur la population, 'Notes par M. le baron De Keverberg', pp. 69-77.

23 About Quetelet's visit to Goethe, see V. John, 'Quetelet bei Goethe', in H. Paasche (ed.), Festgabe für Johannes Conrad. Zur Feier des 25-jährigen Bestehens des staatswissenschaftlichen Seminars zu Halle a. S. (Jena 1898), pp. 313-334.

24 Archives de l'Académie royale de Belgique (Brussels), Archives Quetelet, letter from Heuschling to Quetelet, 17 November 1865.

25 A. Quetelet, Sur l'homme et le développement de ses facultés, ou Essai de physique sociale (Brussels 1836) II, p. 264.

26 A. Quetelet, Du système social et des lois qui le régissent (Paris 1848), pp. 91-92.

27 Letter from V. Gioberti to A. Quetelet, Paris, 24 February 1848, in V. Gioberti, Epistolario, VII (Florence 1934), p. 279.

28 Adolphe Quetelet 1796-1874. Exposition documentaire présentée à la Bibliothèque Royale Albert Ier à l'occasion du centenaire de la mort d'Adolphe Quetelet (Brussels 1974), p. 89.

29 F.H. Hankins, Adolphe Quetelet as Statistician (New York 1908), pp. 76-82.

30 S.M. Stigler, 'Adolphe Quetelet: Statistician, Scientist, Builder of Intellectual Institutions', in Actualité et universalité de la pensée scientifique d'Adophe Quetelet. Actes du colloque organisé à l'occasion du bicentenaire de sa naissance. Palais des Académies 24-25 octobre 1996 (Brussels 1997), pp. 47-61.

31 A. Quetelet, 'Sur le recensement de la population de Bruxelles en 1842', Bulletin de la Commission de Statistique 1 (1843), 72.

$32 \mathrm{X}$. Heuschling, 'Des naissances dans la ville de Bruxelles, considérées dans leur rapport avec la population', Bulletin de la Commission de Statistique 1 (1843), 172.

33 N. Randeraad, 'Negentiende-eeuwse bevolkingsregisters als statistische bron en middel tot sociale beheersing, Tijdschrift voor Sociale Geschiedenis 21 (1995), 328.

34 'Rapport au Ministre de l'intérieur sur la nécessité d'un recensement général de la population du royaume (28 juillet 1843)', Bulletin de la Commission de Statistique 1 (1843), 577-578.

35 Algemene volks-, nijverheids- en handelstelling op 31 december 1947, I (Brussel 1949), p. 9.

36 The account of the census in Bruges is based on the correspondence deposited with the City Archive in Bruges, Hedendaags Archief, Bevolking en burgerlijke stand, Statistiquerecensement de population 1846, no. 1, box VII A 21.

37 A. Quetelet, 'Résultats du recensement de la population. Rapport au Ministre de l'intérieur' (23 December 1846), Bulletin de la Commission de Statistique 3 (1847), 152-155.

38 Archives de l'Académie royale de Belgique (Brussels), Archives Quetelet, no. 1298, letter of 25 December 1846.

39 Compte rendu à Bruxelles 1853, pp.108-113.

40 GStA PK, Report of Dieterici, 17 October 1853.

41 Compte rendu à Bruxelles 1853, p. 87.

42 J. Blum, In the Beginning. The Advent of the Modern Age. Europe in the 1840s (New York 1994), p. 119.

43 GStA PK, Report of Dieterici, 17 October 1853. 